\title{
GENETIC DIVERSITY IN DIFFERENT POPULATIONS OF SLOTHS ASSESSED BY DNA FINGERPRINTING
}

\author{
MORAES, N., MORGANTE, J. S. and MIYAKI, C. Y. \\ Departamento de Biologia, Universidade de São Paulo, C.P. 11.461, CEP 05422-970, São Paulo, SP, Brazil \\ Correspondence to: Nadia de Moraes, Departamento de Biologia, Universidade de São Paulo, \\ C.P. 11.461, CEP 05422-970, São Paulo, SP, Brazil, e-mail: namoraes@ib.usp.br \\ Received December 11, 2000 - Accepted January 17, 2001 - Distributed August 31, 2002
}

(With 1 figure)

\begin{abstract}
In this study we analyzed a population of Bradypus torquatus with individuals originally distributed in different localities of Bahia, and two populations of $B$. variegatus with individuals from Bahia and São Paulo States. Using the DNA fingerprinting method, we assessed the genetic variability within and between populations. Analysis of the DNA profiles revealed genetic similarity indices ranging from $0.34 \pm 0.07$ to $0.87 \pm 0.04$. Similar low levels of genetic variability were found only in isolated mammalian populations or among related individuals. This study presents the first analyses of genetic diversity in sloth populations.
\end{abstract}

Key words: Bradypus: DNA fingerprinting, genetic variability.

\section{RESUMO}

\section{Diversidade genética em diferentes populações de preguiças estimada por intermédio da técnica de DNA fingerprinting}

Neste estudo foram analisadas uma população de Bradypus torquatus composta por indivíduos provenientes de diferentes localidades do Estado da Bahia e duas populações de B. variegatus, uma na Bahia e outra em São Paulo. A estimativa da variabilidade genética dentro e entre as populações foi feita utilizando-se a técnica de DNA fingerprinting. A partir da análise dos padrões de bandas de DNA, foram calculados índices de similaridade genética que variaram de $0,34 \pm 0,07$ a $0,87 \pm 0,04$. Valores semelhantes, que indicam baixa variabilidade genética nas populações de preguiças analisadas, foram encontrados somente em populações de mamíferos isolados ou grupos de indivíduos aparentados. Este trabalho apresenta os primeiros resultados no estudo da diversidade genética em populações de preguiças.

Palavras-chave: Bradypus: DNA fingerprinting, variabilidade genética.

\section{INTRODUCTION}

Sloths are neotropical mammals belonging to the order Xenarthra. They inhabit tropical forest areas of Central and South America (Wetzel, 1982, $1985)$ and are classified in two genera containing five species: the three-toed sloths (Bradypus sp.) and the two-toed sloths (Choloepus sp.) (Emmons, 1990).

All sloth species are found in Brazil, including the maned sloth, Bradypus torquatus, which is considered in danger of extinction (Bernardes $e t$ al., 1990; Baillie \& Groombridge, 1996). Some authors include this species in the genus Scaeopus (Santos, 1977; Paula-Couto, 1979; Wetzel \& ÁvilaPires, 1980), while others treat Scaeopus as a subgenus of Bradypus (Wetzel, 1982). This species is endemic to the eastern and southeastern Atlantic forest (Wetzel \& Ávila-Pires, 1980; Emmons, 1990; Oliver \& Santos, 1991; Fonseca et al., 1994). B. variegatus has a much wider geographic distribution, including most of Brazil and Central Ame- 
rica (Wetzel, 1982; Oliver \& Santos, 1991) and is considered threatened where habitat is destroyed (Emmons, 1990). The Atlantic forest has been subjected to intense levels of disturbance and deforestation since the arrival of Europeans in the early 16th century (Dean, 1995) and today is fragmented and reduced to $5-12 \%$ of the original forest (Brown \& Brown, 1992). To measure the impact that such fragmentation of habitats has on natural populations, the study of the genetic composition and analysis of genetic variability is very important.

The DNA fingerprinting technique has proven successful in measuring genetic diversity in animal populations through the use of human hypervariable minisatellite probes (Jeffreys et al., 1985a) to generate restriction fragment profiles (Blanchetot, 1992; David-Gray et al., 1998; Gilbert et al., 1990; Signer et al., 1994; Tegelström \& Sjöberg, 1995).

Despite a number of cytogenetic and molecular phylogenetic studies (Goldschmidt \& Almeida, 1993; Goldschmidt et al., 1995; Höss et al., 1996; Jorge et al., 1977; Jorge, 1981; Jorge \& Pinder, 1990; Murata \& Matsuda, 1996; Pinder, 1993; Van Dijk et al., 1999), there is as yet no analysis of genetic diversity in sloth populations.

We have used the DNA fingerprinting technique to evaluate the genetic variability of two different species of sloths inhabiting the Atlantic forest. The study is focused on a population of $B$. torquatus from Bahia, and two populations of $B$. variegatus from both Bahia and São Paulo.

\section{MATERIAL AND METHODS}

\section{Study species}

Individuals sampled were captured or received by two governmental institutions: DEPAVE (Departamento de Parques e Áreas Verdes do Estado de São Paulo, Divisão Técnica de Medicina Veterinária e Biologia da Fauna - São Paulo, SP) and CEPLAC - Reserva Zoobotânica (Comissão Executiva do Plano da Lavoura Cacaueira - Itabuna, BA). The animals were originally distributed in different localities within two widely separated Brazilian states, Bahia, and São Paulo, and we assumed that individuals studied in each population are unrelated. A total of 19 sloths were sampled and classified in three populations: one $B$. torquatus population with 9 individuals from Bahia, and two populations of B. variegatus from both Bahia (6 individuals, B. variegatus BA) and São Paulo (4 sloths, B. variegatus SP).

\section{DNA fingerprinting method}

For each sloth at least $6 \mathrm{ml}$ of blood were collected and stored at $-20^{\circ} \mathrm{C}$. Approximately 5$6 \mu \mathrm{g}$ of genomic DNA from each sloth were digested with the restriction enzyme $\mathrm{Mbo}$ I at $37^{\circ} \mathrm{C}$. All samples were electrophoresed in a $1 \%$ agarose gel $(20 \times 30 \mathrm{~cm})$ at $40 \mathrm{~V}$ for $72 \mathrm{~h}$ (when the 2.3 kilobase $(\mathrm{kb}) \lambda$ Hind III band migrated to the bottom of the gel). DNA fragments were transferred to a nylon membrane (Hybond-Nfp, Amersham) by capillary Southern blotting (Sambrook et al., 1989).

The same membrane was hybridized with minisatellite 33.6 and 33.15 probes (Jeffreys et al., 1985a), which were labeled by random priming with $\left[\alpha-{ }^{32} \mathrm{P}\right] \mathrm{dCTP}$. Pre-hybridization in $0.263 \mathrm{M}$ $\mathrm{Na}_{2} \mathrm{HPO}_{4}, 1 \mathrm{mM}$ EDTA, $7 \%$ SDS, and 1\% BSA at $65^{\circ} \mathrm{C}$ lasted for $4 \mathrm{~h}$, then one of the probes was added and left overnight at the same temperature. The membrane was washed in $0.25 \mathrm{M} \mathrm{Na}_{2} \mathrm{HPO}_{4}$, $1 \%$ SDS; $2 \mathrm{XSSC}, 0.1 \% \mathrm{SDS}$, and $1 \mathrm{XSSC}, 0.1 \%$ SDS at $65^{\circ} \mathrm{C}$. The filter was then autoradiographed at $-70^{\circ} \mathrm{C}$ using Kodak RX film with one or two intensifying screens.

The patterns of eletrophoretic migration were analyzed and only the bands between 23 and $4 \mathrm{~kb}$ were marked on acetate overlays as described by Westneat (1990). Only bands of the same electrophoretic mobility (migration distance of band centers within $0.5 \mathrm{~mm}$ ) between two individuals were considered identical. We used the band-sharing coefficient, $x$ (index of band similarity between two individuals), and the individual specificity of the DNA fingerprints, $x^{n}$ (the probability that two unrelated individuals would have an identical fingerprint), for assessing genetic variability. The band sharing coefficient (index of similarity) between the individuals was calculated using the formula: $\mathrm{x}=2 \mathrm{~N}_{\mathrm{AB}} /\left(\mathrm{N}_{\mathrm{A}}+\mathrm{N}_{\mathrm{B}}\right)$, where $\mathrm{N}_{\mathrm{AB}}$ is the number of bands shared between the individuals $\mathrm{A}$ and $\mathrm{B}$, and $\mathrm{N}_{\mathrm{A}}$ and $\mathrm{N}_{\mathrm{B}}$ are the number of bands present in individuals $\mathrm{A}$ and $\mathrm{B}$, respectively (Wetton et al., 1987; Bruford et al., 1992). Assuming that each band represents an independent marker, the mean probability that all bands in an individual's pattern are present in another unrelated individual chosen at random is $x^{\mathrm{n}}$, where $x$ corresponds to the mean 
band sharing coefficient and $n$, the mean number of scored bands (Jeffreys et al., 1985a). For statistical analysis we used a Mann-Whitney test.

\section{RESULTS}

Hybridization of 33.6 and 33.15 probes to Mbo I digested sloth DNA samples revealed informative band patterns in both $B$. torquatus and $B$. variegatus (Fig. 1). The 33.6 probe detected a restriction fragment found exclusively among all individuals of $B$. torquatus while the 33.15 probe detected another band present only in all individuals from B. variegatus (Fig. 1).
We observed very similar band patterns among individuals from the $B$. variegatus SP population and consequently higher values of mean bandsharing coefficients $(0.87 \pm 0.04$ using the 33.6 probe and $0.62 \pm 0.06$ for the 33.15 probe). The B. variegatus BA population presents mean bandsharing coefficients of $0.57 \pm 0.08$ using 33.6 probe, and $0.51 \pm 0.06$ with 33.15 probe while for the $B$. torquatus population these values were $0.53 \pm$ 0.08 and $0.34 \pm 0.07$ for 33.6 and 33.15 probe, respectively (Table 1 ). Using both probes, the estimated probability that two DNA profiles would be identical can be considered low and adequate for our purposes (Table 1).

$\mathrm{kb}$

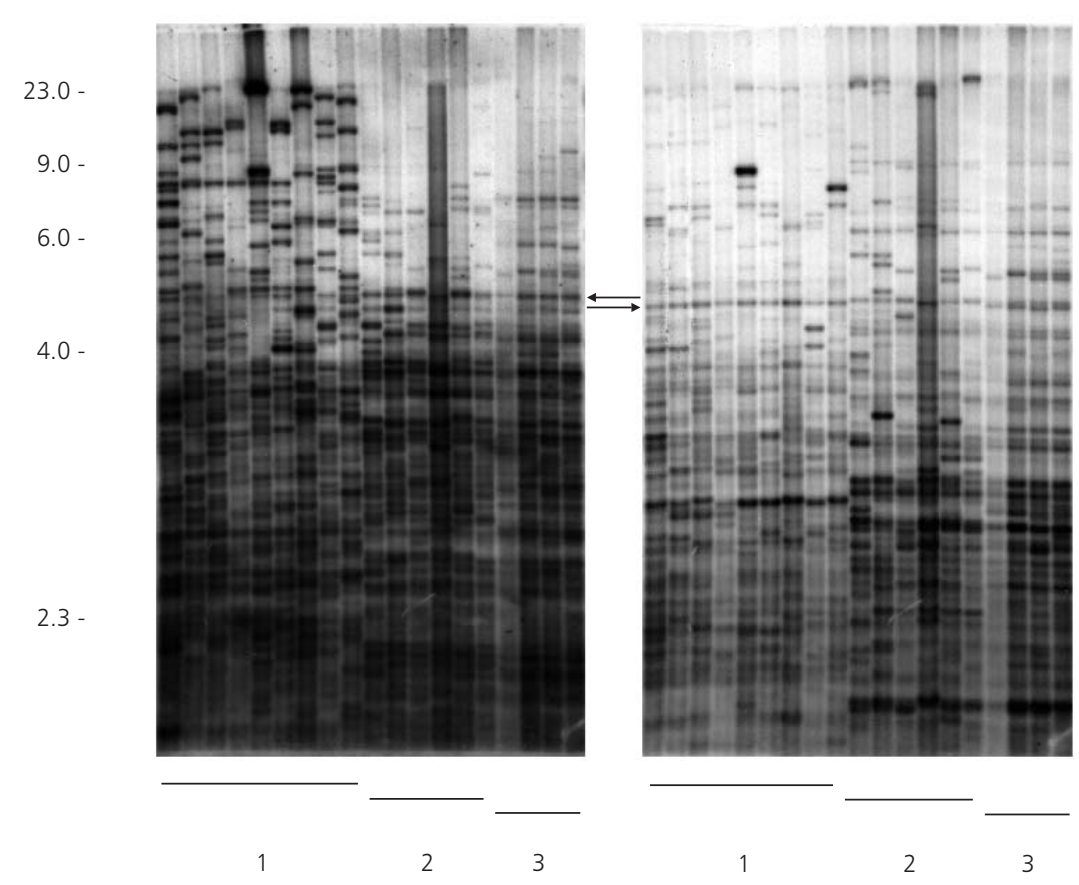

Fig. 1 - DNA fingerprints of unrelated sloths of three populations: $1-$ B. torquatus; $2-$ B. variegatus Bahia; $3-$ B. variegatus São Paulo. The same membrane was hybridizated with 33.15 (A) and 33.6 (B) probes. The 33.15 probe detected a band present only on all individuals from $B$. variegatus species while the 33.6 probe detected another restriction fragment found exclusively among all individuals of $B$. torquatus (see arrows). 
TABLE 1

Comparative DNA fingerprint data for sloth populations using two different probes. Number of comparisons among individuals within population (N), average number of DNA fragments scored for each animal (n), and mean band-sharing coefficient $(x)$, are given. The propability that two unrelated individuals would have an identical fingerprint $\left(x^{n}\right)$ and standard error $( \pm$ se) are also shown.

\begin{tabular}{|c|c|c|c|c|c|c|c|}
\hline \multirow{2}{*}{ Population } & \multirow{2}{*}{$\mathbf{N}$} & \multicolumn{3}{|c|}{33.15 probe } & \multicolumn{3}{|c|}{ 33.6 probe } \\
\hline & & $\mathbf{n} \pm \mathbf{s e}$ & $\mathbf{x} \pm \mathrm{se}$ & $x^{n}$ & $\mathbf{n} \pm \mathbf{s e}$ & $\mathbf{x} \pm \mathrm{se}$ & $x^{n}$ \\
\hline Bradypus torquatus & 36 & $35.33 \pm 3.35$ & $0.34 \pm 0.07$ & $2.80 \times 10^{-17}$ & $36.33 \pm 4.15$ & $0.53 \pm 0.08$ & $9.62 \times 10^{-11}$ \\
\hline $\begin{array}{c}\text { Bradypus variegatus } \\
\text { BA }\end{array}$ & 15 & $32.17 \pm 3.66$ & $0.51 \pm 0.06$ & $3.91 \times 10^{-10}$ & $38.01 \pm 2.01$ & $0.57 \pm 0.08$ & $5.26 \times 10^{-10}$ \\
\hline Bradypus variegatus SP & 6 & $38.25 \pm 5.74$ & $0.62 \pm 0.06$ & $1.14 \times 10^{-8}$ & $36.25 \pm 2.75$ & $0.87 \pm 0.04$ & $6.4 \times 10^{-3}$ \\
\hline
\end{tabular}

The mean pairwise band-sharing coefficients calculated between individuals from $B$. variegatus BA and B. variegatus SP populations were $0.41 \pm$ 0.06 for the 33.15 probe, and $0.41 \pm 0.08$ using the 33.6 probe, and are lower than those found within these two populations (Table 2).

\section{DISCUSSION}

Our indices of mean band-sharing coefficients for both probes, 33.15 and 33.6, exceeds the value, around 0.2 , that has been reported for human (Jeffreys et al., 1985b) and natural populations (Wetton et al., 1987; Baker et al., 1993) and reveal low genetic variability within the sloth populations we studied.

The highest mean band-sharing coefficients were observed for the B. variegatus SP population and are similar to the very high values found for a California Channel Island fox population (Gilbert et al., 1990), a first-order relationship group of black bears (Schenk \& Kovacs, 1996), Swedish beavers (Ellegren et al., 1993), and the koala bear (Cocciolone \& Timms, 1992; Timms et al., 1993). The medium values obtained for Bradypus variegatus BA population with both probes, 33.6 and 33.15, are higher than those reported for unrelated chamois (Pérez et al., 1996) and forest islands red squirrels (Wiegand \& Schröpfer, 1997). In the B. torquatus population, the estimated genetic variability by using 33.15 probe is similar to the low levels found in unrelated red squirrel using the same probe (Wiegand \& Schröpfer, 1997).

These results suggest low levels of genetic variability in the sloth populations. Comparing the two populations of $B$. variegatus, we also observed a significant regional difference in the levels of genetic variation between São Paulo and Bahia populations ( $p<0.01$ for values obtained with each probes). In addition, we noted that these two groups of individuals are genetically distinct at hypervariable minisatellite loci (Table 2), an expected divergence since these two populations inhabit very distant geographical regions.

TABLE 2

Values of mean band-sharing coefficients between individuals of the two $\mathrm{B}$. variegatus populations obtained with two different minissatelite human probes.

\begin{tabular}{|c|c|c|}
\hline & \multicolumn{2}{|c|}{ Bradypus variegatus BA } \\
\hline Bradypus variegatus SP & $41 \pm 0.06^{1}(33.15$ probe $)$ & $0.41 \pm 0.08^{1}(33.6$ probe $)$ \\
\hline
\end{tabular}

1. Values of mean band-sharing coefficients \pm standard errors. 
Even though the number of samples available at this time is too small for drawing strong conclusions, the data presented here result from the first genetic study of sloth populations and show low variability for the groups studied. The individuals sampled were originally distributed in different localities of two large geographical regions and probably represent different populations within Bahia and São Paulo. Nevertheless, the values of mean band-sharing coefficients detected within the populations are higher than those reported between some mammal subpopulations and even within populations.

These high values for similarity could be either a characteristic observed only in these sloth populations or a general characteristic of the species. Further molecular characterization of these and other sloth populations are needed to evaluate the causes of this low variability, specially in the B. variegatus SP population which showed the higher values for similarity. However, we believe that in the populations here studied the lack of genetic diversity could be explained by bottleneck and founder effects.

Acknowledgments - The authors wish to thank biologist Vera Lúcia de Oliveira from CEPLAC - Reserva Zoobotânica (Bahia) and DEPAVE (Departamento de Parques e Áreas Verdes do Estado de São Paulo, Divisão Técnica de Medicina Veterinária e Biologia da Fauna) for the biological material used in this work. We also thank Anita Wajntal, Renato Caparroz, Silvia Geurgas, Albert Ditchfield, and Eugene I. Harris for suggestions. Financial support was given by CAPES, CNPq, and FAPESP. The Jeffreys' probes 33.15 and 33.6 are registered under patent \# GBA 2166445 and used worldwide for commercial diagnosis.

\section{REFERENCES}

BAKER, C. S., GILBERT, D. A., WEINRICH, M. T., LAMBERTSEN, R., CALAMBOKIDIS, J., McARD CHAMBERS, G. K. \& O'BRIEN, S. J., 1993, Population characteristics of DNA fingerprints in humpback whales (Megaptera novaeangliae). J. Hered., 84: 281-290.

BAILLIE, J. \& GROOMBRIDGE, B., 1996, Red list of threatened animals. IUCN, Gland, Switzerland and Cambridge, UK, 448p.

BERNARDES, A. T., MACHADO, A. B. M. \& RYLANDS, A. B., 1990, Fauna brasileira ameaçada de extinção. Fundação Biodiversitas, Belo Horizonte, 62p.

BLANCHETOT, A., 1992, DNA fingerprinting analysis in the solitary bee Megachile rotuntata: variability and nest mate genetic relationships. Genome, 35: 681-688.
BROWN, K. S. Jr. \& BROWN, G. G., 1992, Habitat alteration and species loss in Brazilian forests. In: T. C. Whitmore \& J. A. Sayer (eds.), Tropical deforestation and species extinction. Chapman \& Hall, London, pp. 119-142.

BRUFFORD, M. W., HANOTTE, O., BROOKFIELD, J. F. Y. \& BURKE, T., 1992, Single locus and multilocus DNA fingerprinting. In: C. A. R. Hoelzel (ed.), Molecular genetics analysis of populations: a practical aproach. Oxford University Press, New York, pp. 225-269.

COCCIOLONE, R. A. \& TIMMS, P., 1992, DNA profiling of Queensland koalas reveals sufficient variability for individual identification and parentage determination. Wildl. Res., 19: 279.

DAVID-GRAY, Z. K., GUENELL, J. \& HUNT, D. M., 1998, DNA fingerprinting reveals high levels of genetic diversity within British populations of the introduced non-native grey squirrel (Sciurus carolinensis). J. Zool., 246: 443-486.

DEAN, W., 1995, With broadaxe and firebrand: the destruction of the Brazilian Atlantic forest. University of Califormia Press, Berkley, 197p.

ELLEGREN, H., HARTMAN, G., JOHANSSON, M. \& ANDERSSON, L., 1993, Major histocompatibility complex monomorphism and low levels of DNA fingerprinting variability in a reintroduced and rapidly expanding population of beavers. Proc. Natl. Acad. Sci. U.S.A., 90: 8150-8153

EMMONS, L., 1990, Neotropical rainforest mammals. University of Chicago Press, Chicago, 281p.

FONSECA, G. A. B., RYLANDS, A. B., COSTA, C. M. R., MACHADO, R. B. \& LEITE, Y. L. R., 1994, Livro vermelho dos mamíferos brasileiros ameaçados de extinção. Fundação Biodiversitas, Belo Horizonte, 459p.

GILBERT, D. A., LEHMAN, N., O'BRIEN, S. J. \& WAYNE, R. K., 1990, Genetic fingerprinting reflects population differentiation in the California Channel Island fox. Nature, 344: 764-766.

GOLDSCHMIDT, B. \& ALMEIDA, J. C. C., 1993, Cytogenetic studies in sloths (Bradypus variegatus). Rev. Bras. Gen., 16: 939-948.

GOLDSCHMIDT, G., ALMEIDA, J. C. C. \& OLIVEIRA, V. L., 1995, Visualization of nucleolar organizer regions in sloths (Bradypus variegatus and Scaeopus torquatus). Rev. Bras. Gen., 18: 111-113.

HÖSS, M., DILLING, A., CURRANT, A. \& PÄÄBO, S., 1996, Molecular phylogeny of the extinct ground sloth Mylodon darwinii. Proc. Natl. Acad. Sci. U.S.A, 93: 181-185.

JEFFREYS, A. J., WILSON, V. \& THEIN, S. L., 1985a, Hypervariable minisatellite regions in human DNA. Nature, 314: 67-73.

JEFFREYS, A. J., WILSON, V. \& THEIN, S. L., 1985b, Individual specific "fingerprints" of human DNA. Nature, 316 : 76-79.

JORGE, W., 1981, Estudo cromossômico de algumas espécies da ordem Edentata. Tese de Livre-docência, Universidade do Estado de São Paulo, 195p. 
JORGE, W., MERITT, D. \& BENIRSCHKE, K., 1977, Chromosome studies in Edentata. Cytobios, 18: 157-172.

JORGE, W. \& PINDER, L., 1990, Chromosome study on the maned sloth Bradypus torquatus (Bradypodidae, Xenarthra). Cytobios, 62: 21-25.

MURATA, K. \& MATSUDA, R., 1996, Gender determination of the Linne's two-toed sloth (Choloepus didactylus) using SRY amplified from hair. J. Vet. Med. Sci., 58: 11571159.

OLIVER, W. L. R. \& SANTOS, I. B., 1991, Threatened endemic mammals of the Atlantic forest region of southeastern Brazil. Wildl. Pres. Tr. Spec. Sci. Rep., 4: 1-126.

PAULA-COUTO, C., 1979, Tratado de paleomastozoologia. Academia Brasileira de Ciências, Rio de Janeiro, 590p.

PÉREZ, T., ALBORNOZ, J., GARCIA-VASQUEZ, E. \& DOMÍNGUEZ, A., 1996, Application of DNA fingerprinting to population study of chamois (Rupicapra rupicapra). Bioch. Genet., 34: 313-320.

PINDER, L., 1993, Body measurements, karyotype, and birth frequencies of Maned Sloth (Bradypus torquatus). Mammalia, 57: 43-48

SAMBROOK, J., FRITSCH, E. F. \& MANIATIS, T., 1989, Molecular cloning: a laboratory manual. 2. ed., 3. vol., Cold Spring Harbor Laboratory Press, New York, 253p.

SANTOS, T. M. S., 1977, Osteologia craniana de Bradypus Linnaeus, 1758 e reavaliação do gênero Scaeopus Peters, 1865. Dissertação de Mestrado, Universidade Federal do Rio Grande do Sul, 178p.

SCHENK, A. \& KOVACS, K. M., 1996, Genetic variation in a population of black bears as revealed by DNA fingerprinting. J. Mamm., 77: 942-950.

SIGNER, E. N., SCHMIDT, C. R. \& JEFFREYS, A. J., 1994, DNA variability and parentage testing in captive Waldrapp ibises. Mol. Ecol., 3: 291-300.
TEGELSTRÖM, H. \& SJÖBERG, G., 1995, Introduced Swedish Canada geese (Branta canadensis) have low levels of genetic variation as revealed by DNA fingerprinting. J. Evol. Biol., 8: 195-207.

TIMMS, P., KATO, J., MAUGERI, M. \& WHITE, N., 1993, DNA fingerprint analysis of a free-range koala population. Bioch. Genet., 31: 363-374.

VAN DIJK, M. A. M., PARADIS, E., CATZEFLIS, F. \& DE JONG, W. W., 1999, The virtues of gaps: Xenarthran (Edentate) monophyly supported by a unique deletion in aA-crystallin. Syst. Biol., 48: 94-106.

WESTNEAT, D. F., 1990, Genetic parentage in the indigo butting: a study using DNA fingerprinting. Beh. Ecol. Sociob., 27: 67-76.

WETTON, J. H., CARTER, R. E., PARKIN, D. T. \& WALTERS, D., 1987, Demographic study of a wild house sparrow population by DNA fingerprinting. Nature, 327: 147-149.

WETZEL, R. M., 1982, Systematics, distribution, ecology, and conservation of South American Edentates. In: M. A. Mares \& H. H. Genoways (eds.), Mammalian biology in South America, special publication series, Pymatuning laboratory of ecology. University of Pitsburgh, Linesville, pp. 345-375.

WETZEL, R. M., 1985, The identification and distribution of recent Xenarthra (= Edentata). In: G. G. Montgomery (ed.), The evolution and ecology of armadillos, sloths, and vermilinguas. Smithsonian Institution Press, Washington, pp. 5-21.

WETZEL, R. M. \& ÁVILA-PIRES, F. D., 1980, Identification and distribution of the recent sloths of Brazil (Edentata). Rev. Bras. Biol., 40: 831-836.

WIEGAND, P. \& SCHRÖPFER, R., 1997, DNA fingerprinting analysis of subpopulation of the red squirrel (Sciurus vulgaris, L. 1758). J. Zool. Syst. Evol. Res., 35: 71-74. 